\title{
The impact of extreme weather events on the seagrass Zostera noltii and related Hydrobia ulvae population
}

\author{
P.G. Cardoso ${ }^{\text {a,* }}$, D. Raffaelli ${ }^{\text {b }}$, M.A. Pardal ${ }^{\text {a }}$ \\ ${ }^{a}$ IMAR - Institute of Marine Research, Department of Zoology, University of Coimbra, 3004-517 Coimbra, Portugal \\ ${ }^{\mathrm{b}}$ Environment Department, University of York, Heslington, York, YO10 5DD, UK
}

\begin{abstract}
Coastal areas are typically subjected to a range of stressors, but they now face the additional stressor of climate change, manifested in part by an increased intensity and frequency of extreme weather events. Thus, the Mondego estuary (Portugal) has experienced organic enrichment (eutrophication) issues and these are potentially exacerbated by extreme weather events (floods, droughts and heat waves). In this paper, we explore the impact of interactions of these different stressors on the ecology of the system, specifically on the two key components, the seagrass Zostera noltii and the mud snail Hydrobia ulvae.

Extreme events affected different components of the estuarine ecosystem (primary producers and macrofauna) differently. Whilst the floods directly impacted on $H$. ulvae, by wiping out part of its population, they did not directly affect the biomass of $Z$. noltii. In contrast, drought events, through their effects on salinity, directly impacted the biomass of Zostera, which had knock-on effects on the dynamics of $H$. ulvae.

We conclude that over the period when the estuary experienced eutrophication, extreme weather events contributed to the overall degradation of the estuary, while during the recovery phase following the introduction of a management programme, those extreme weather episodes delayed the recovery process significantly.
\end{abstract}

(c) 2007 Elsevier Ltd. All rights reserved.

Keywords: Extreme events; Floods; Droughts; Eutrophication; Zostera noltii; Hydrobia ulvae

\section{Introduction}

Coastal zones and shallow marine habitats are among the most productive ecosystems on Earth, and in many locations they are subjected to a variety of anthropogenic stressors, such as pollution and eutrophication. These, damage the health and robustness of the fauna and flora through their separate, cumulative and synergistic effects, lowering the overall stability of these ecosystems (Adams, 2005). Now, such ecosystems face the additional stressor of climate change (Struyf et al., 2004), and the combined effects of all of these stressors are difficult to predict. Climate change impacts on coastal habitats through accelerated sea-level rise, direct warming and increased frequency of extreme weather events, such as storms and floods. Here, we explore

\footnotetext{
* Corresponding author. Tel.: +351 239837797; fax: +351 239823603.

E-mail address: gcardoso@ci.uc.pt (P.G. Cardoso).
}

the impact of the interactions of different stressors on the ecology of a well-documented estuary in Portugal, the Mondego. This area has experienced significant eutrophication over the past 20 years, which has led to a decline in the environmental quality of the estuary, specifically replacement of seagrasses by opportunistic macroalgae, degradation of water quality and increased turbidity (Pardal et al., 2004; Cardoso et al., 2005, 2007; Verdelhos et al., 2005; Dolbeth et al., 2007) and a management programme, which included measures to decrease nutrient loading, physical protection of the seagrass bed and improvement of water dynamics, was introduced in 1998 (Cardoso et al., 2005, 2007; Lillebø et al., 2005; Verdelhos et al., 2005; Dolbeth et al., 2007). At the same time, there has been a well-documented increase in mean air temperature of $0.15^{\circ} \mathrm{C}$ per decade from 1931 to 2005 and a higher frequency of heat waves in the last decade (e.g. in 2003 and 2005) (IM - Portuguese Weather Institute, http://www.meteo.pt/pt/clima). 
Heavy rainfall events have also increased in frequency. Between 1931 and 2000, the rainfall data for mainland Portugal show an increase in the frequency of heavy rainfall and the maximum 5-day total precipitation, an indicator of flood producing events, has also increased (Santos et al., 2002). Here, we explore a 12-year time-series for evidence of interactions between climate and other stressors on the ecology of the Mondego estuary, specifically on two key aspects of the flora and fauna, the seagrass Zostera noltii and the mud snail Hydrobia ulvae.

\section{Materials and methods}

\subsection{Study site and climate variability}

The Mondego estuary, located on the Atlantic coast of Portugal $\left(40^{\circ} 08 \mathrm{~N}, 8^{\circ} 50 \mathrm{~W}\right)$ consists of two distinct arms, northern and southern, separated by Murraceira Island (Fig. 1). A detailed description of the system can be found in Cardoso et al. (2004, 2005); Verdelhos et al. (2005).

Two distinct areas were selected as sampling sites along the southern arm: the seagrass $Z$. noltii bed towards the marine end of the estuary and a eutrophic area further upstream (Fig. 1). In the 1980s, the Z. noltii bed occupied a broad expanse (15 ha) along the southern arm reaching the inner most parts of the estuary (Cardoso et al., 2005). By the mid-1990s, Z. noltii had become restricted to a small patch $(0.02$ ha) located downstream, having been replaced elsewhere by blooms of opportunistic green macroalgae. The eutrophic area located upstream comprises sandymuddy sediment, which in the early 1980 s was covered by $Z$. noltii, but as eutrophication increased, $Z$. noltii declined (Cardoso et al., 2005). This area has less energetic hydrodynamics and is covered seasonally by green macroalgae

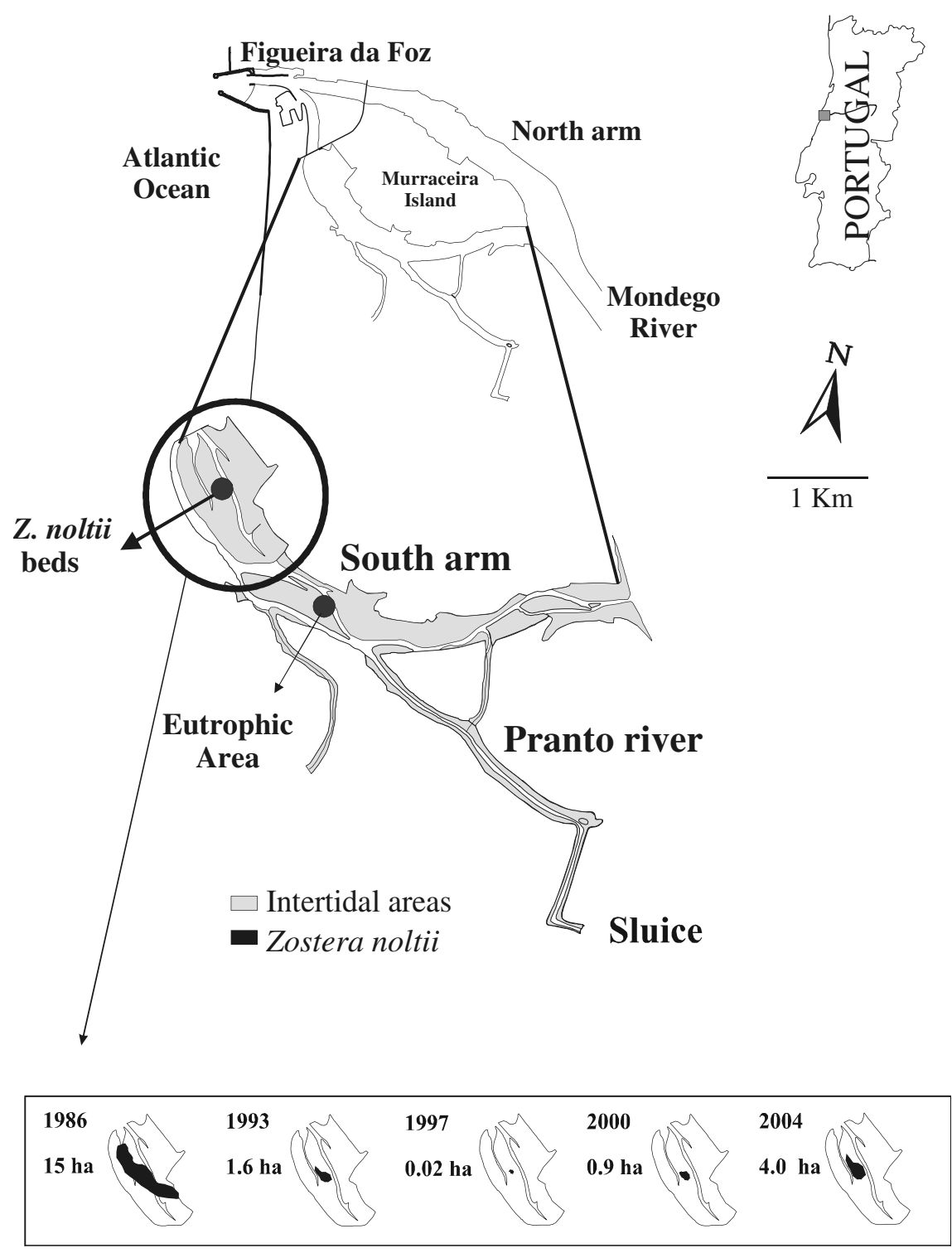

Fig. 1. Location of the sampling stations and change in the area covered by $Z$. noltii in the south arm of the Mondego estuary. Mapping of benthic vegetation is based on field observations, aerial photographs and GIS methodology (ArcView GIS version 8.2). 
(Ulva spp.) (Martins et al., 2001; Cardoso et al., 2002, 2004; Ferreira et al., 2004; Pardal et al., 2004).

In the eutrophic area, the $H$. ulvae population was monitored from January 1993 to January 1997 and again from January 1999 to December 2005. In the seagrass bed, the population was monitored from January 1993 to September 1995 and again from January 1999 to December 2005. From 1997 to 1998 the areas were not sampled in order to facilitate recovery of the seagrass bed.

Samples were collected fortnightly for the first 18 months of study and monthly for the rest of the study period. On each occasion, $6-10$ sediment cores $\left(141 \mathrm{~cm}^{2}\right.$ surface area) were taken to a depth of $15 \mathrm{~cm}$ and washed in estuarine water through a $500 \mu \mathrm{m}$ mesh sieve. The material retained (sediment, rooted macrophytes, algae and fauna) was fixed and preserved in $4 \%$ buffered formalin.

\subsection{Seagrass and macroalgal analysis}

In the laboratory, plant material was sorted and separated into Chlorophycea, Rhodophycea and $Z$. noltii (leaves and rhizomes). The plant material was dried (for $48 \mathrm{~h}$ at $60^{\circ} \mathrm{C}$ ) and the ash-free dry weight (AFDW) assessed after combustion of samples for $8 \mathrm{~h}$ at $450{ }^{\circ} \mathrm{C}$.

\subsubsection{Hydrobia ulvae}

Hydrobia ulvae were counted and measured (methods detailed in Cardoso et al., 2005). Biomass was estimated as ash-free dry weight (AFDW) (loss after $8 \mathrm{~h}$ of incineration at $450{ }^{\circ} \mathrm{C}$ ).

Annual net production estimates $(\mathrm{P})$ based on cohort recognition, were estimated as described in Dauvin (1986) (for full details, see Cardoso et al., 2005).

\subsection{Climate data}

Rainfall data were obtained monthly from the nearby city of Coimbra (Instituto de Meteorologia, Coimbra forecast station). An analysis was also made of the available information on drought conditions, by constructing a drought index, based on a Decis - classification (http:// www.meteo.pt/pt/clima/clima_seca3.html). Rainfall data are divided in 10 equal parts, delimited by $1^{\circ}$ decil, $2^{\circ}$ decil, and so on until the $10^{\circ}$ decil, to provide the following classification:

\begin{tabular}{ll}
\hline Inter-decis interval & Qualitative designation \\
\hline 1 & Extremely dry \\
2 & Very dry \\
3,4 & Dry \\
5,6 & Normal \\
7,8 & Rainy \\
9 & Very rainy \\
10 & Extremely rainy \\
\hline
\end{tabular}

\section{Results}

\subsection{Regional climate change}

Analysis of the seasonal accumulated precipitation for the centre of Portugal for the last 60 years revealed many rainfall events in excess the mean winter precipitation of $406 \mathrm{~mm}$ (Fig. 2A). However, the frequency of flood events, defined here as precipitation in excess of $50 \%$ of the winter mean, has clearly increased over the last 30 years. Between 1940 and the mid-1960s, no flood events were recorded, but since then the frequency of flooding events has increased substantially (Fig. 2B).

Over the last 30 years (1970-2005), the frequency and intensity of dry years has also increased, compared to the previous 30 years (1940-1970) (Fig. 3A). Between 1940 and 1970, 1 extremely dry year, 1 very dry year and 6 dry years were recorded, while after 1970 there have been 2 extremely dry years, 2 very dry years and 11 dry years.

Finally, from 1945 to the mid 1970s there was a slight decrease in mean summer temperatures, but from the mid 1970s to date there has been a period of increasing warming (Fig. 3B).

\subsection{Local (estuary-scale) climate data}

The Mondego estuary is part of a warm temperate coastal system with a Mediterranean temperate climate. It experiences a clear seasonal pattern of precipitation with higher rainfall periods during winter. Comparing the Mondego precipitation regime with the mean rainfall pattern for the centre of Portugal for the period of 19611990 (winter: $406 \mathrm{~mm}$, spring: $257 \mathrm{~mm}$, summer: $79 \mathrm{~mm}$, autumn: $272 \mathrm{~mm}$; IM - Portuguese Weather Institute, http://web.meteo.pt), reveals flood events in 1993/1994 (autumn: $593 \mathrm{~mm}$ ), 1995/1996 (winter: $670 \mathrm{~mm}$ ), 2000/ 2001 (winter: $767 \mathrm{~mm}$ ) and 2002/2003 (winter: $645 \mathrm{~mm}$ ). In addition, intense drought events were observed in 2001/2002 (winter: $85.2 \mathrm{~mm}$ ) and 2004/2005 (winter: $31.9 \mathrm{~mm}$ ) (Fig. 4A).

The Mondego has a seasonal temperature pattern with higher temperatures during summer and lower values during winter. However, since the 1990s, a higher frequency of heat waves has been recorded. Comparisons between the Mondego temperatures and those for the period 19611990 (climate normal, mean temperatures: winter: $10^{\circ} \mathrm{C}$, spring: $14^{\circ} \mathrm{C}$, summer: $21^{\circ} \mathrm{C}$, autumn: $17^{\circ} \mathrm{C}$ ) for the centre of Portugal, reveal heat waves in August 2003 (mean temp.: $23.8^{\circ} \mathrm{C}$ ) and in August 2005 (mean temp.: $23.4^{\circ} \mathrm{C}$ ) (Fig. 4B).

\subsection{Seagrass and macroalgal biomass}

The biomass of seagrass $Z$. noltii, differed before and after the implementation of a management plan initiated 

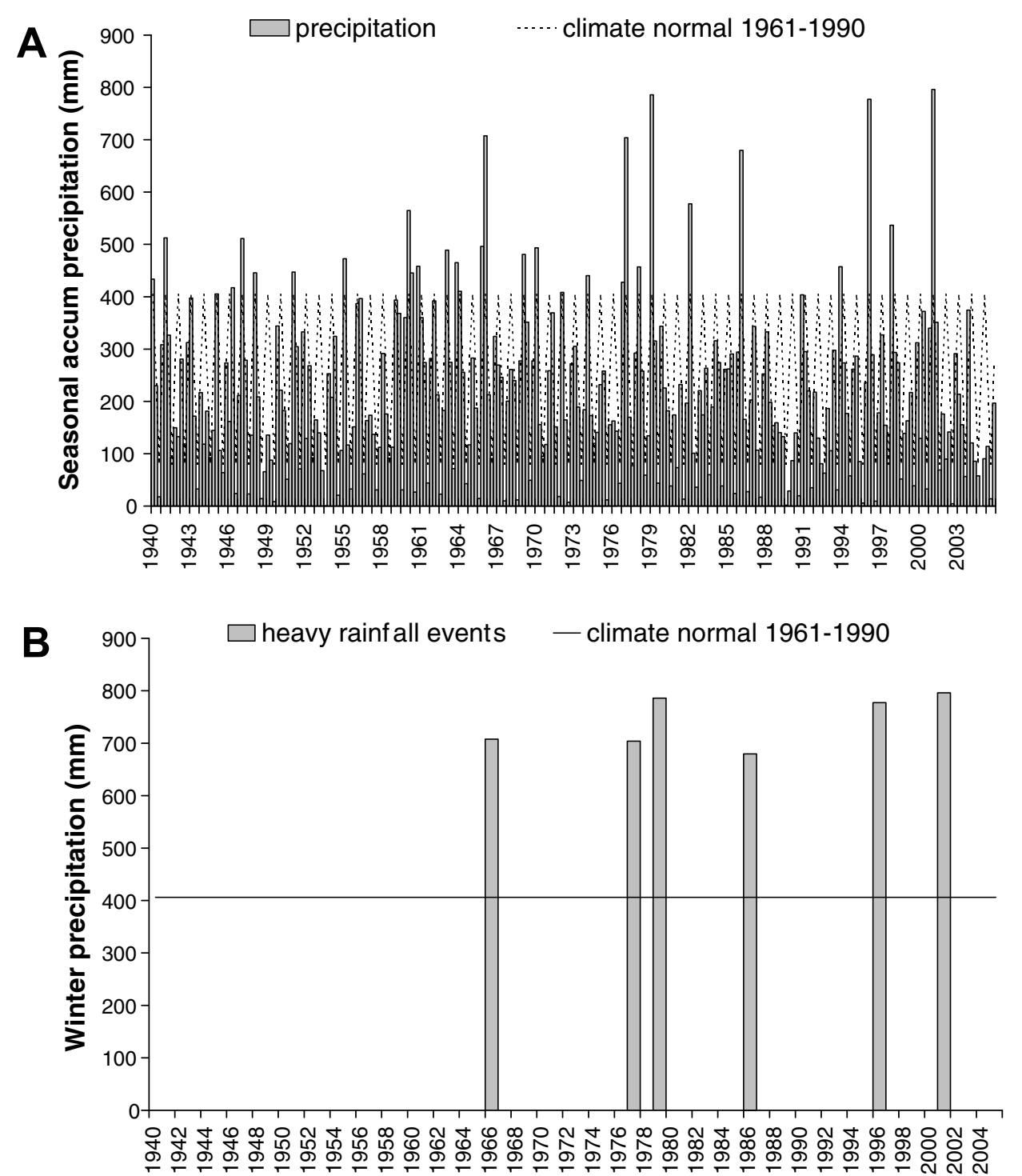

Fig. 2. (A) Seasonal accumulated precipitation for the centre of Portugal from 1940 to 2005 and (B) frequency of flood events (assuming values in excess of $50 \%$ of the winter mean), for the centre of Portugal from 1940 to 2005.

in 1998 (Wilcoxon two-sample test, $W=5963, P<0.05$ ). From 1993 to 1997, there was a marked decline in Z. noltii biomass, following eutrophication. After the management plan was introduced, $Z$. noltii seemed to recover, but during the winter of 2001/2002 an extreme drought had a negative impact on the recovery process, leading to a further decline. In addition, during subsequent years, other extreme weather events, such as the heat wave during the summer of 2003 and the extreme drought followed by a heat wave in 2005, seem to have stopped recovery of the seagrass. It is likely that drought events have greater negative impact on seagrass than floods, since salinity can reach high values during drought episodes and this can negatively affect seagrass survival (Fig. 5A).

In the eutrophic area, the biomass of green macroalgae tended to decrease throughout the study period. In 1993 and 1995, algal blooms were common, but were never present after management. However, some peaks of green mac- roalgae were recorded in the spring of 2000 and also in 2003 and 2005, corresponding to drier years (Fig. 5B).

\subsection{Hydrobia abundance}

Hydrobia ulvae abundance and biomass changed markedly over the study period. Significant differences in $H$. ulvae biomass were observed between the pre- and postmanagement period ( $H$. ulvae biomass in the seagrass bed: Wilcoxon two-sample test, $W=2353, P<0.05$ ). In the seagrass bed, from 1993 to $1995, H$. ulvae biomass was relatively constant (range $50-100 \mathrm{~g} \mathrm{~m}^{-2}$ ). Following the decline of $Z$. noltii, the biomass of $H$. ulvae was reduced by about an order of magnitude (Fig. 6A). After the implementation of management measures, $H$. ulvae started to recover until the autumn of 2000 . However, the intense floods of 2000/2001 caused a further decline in both density and biomass. Following this extreme event, an intense 

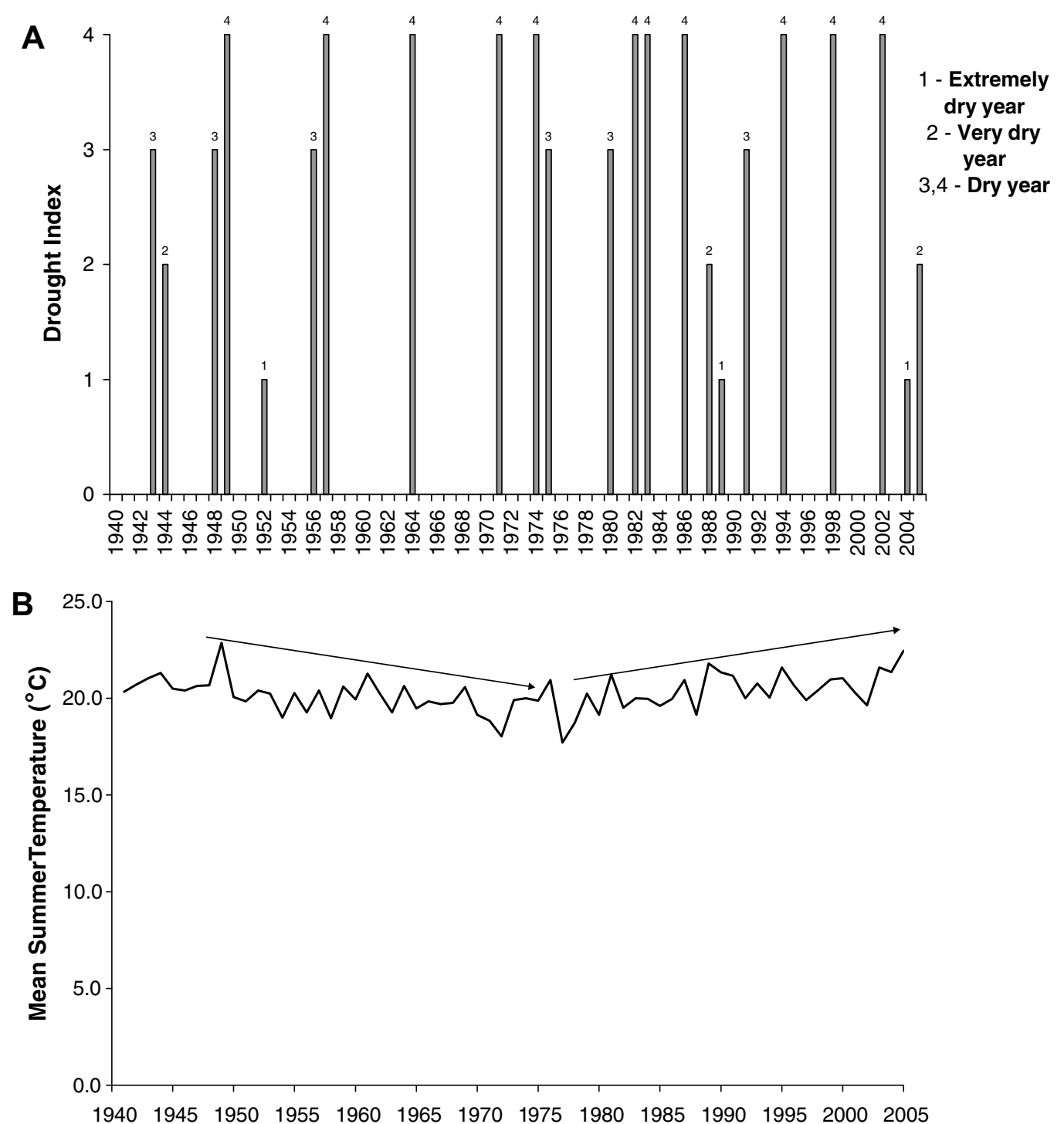

Fig. 3. (A) Drought index based on the inter-decis interval for the centre of Portugal from 1940 to 2005 and (B) mean summer temperature for the centre of Portugal from 1940 to 2005.

drought had an additional negative impact on $H$. ulvae. During 2002, the species recovered, but an intense heat wave occurred in 2003, followed by a severe drought and a heat wave in 2005, further delaying recovery. It seems that flood events have a direct negative impact on this species, by removing part of the population, whilst droughts and heat waves seem to have an indirect negative impact, through the decline of the Hydrobia habitat, the Z. noltii bed.

In the eutrophic area, both density and biomass of $H$. ulvae declined generally throughout the study period, except in 2004 and 2005 when there was a slight increase (Fig. 6B), probably associated with the green macroalgal biomass. Significant differences in $H$. ulvae biomass were observed between the pre- and post-management period ( $H$. ulvae biomass in the eutrophic area: Wilcoxon twosample test, $W=3120, P<0.05)$. In this area, the effect of extreme events was not so apparent, probably because the population was low.

\section{Production}

Hydrobia ulvae always had higher growth production $(\mathrm{P})$ and mean population biomass $(\bar{B})$ in the seagrass bed, compared to the eutrophic area, despite the high variation recorded throughout the study period. Table 1 indicates two distinct time periods, the first associated with eutrophication and the second with the recovery phase after the introduction of management measures.

In the $Z$. noltii bed, the highest values of $\mathrm{P}$ and $\bar{B}$ were recorded in 1994 and since then there has been a decline in both parameters. The recovery phase is characterised by oscillations, probably due to a series of extreme weather events (floods, droughts and heat waves). Thus in 2000, the $H$. ulvae population showed some signs of recovery, but the 2000/2001 floods followed by the 2001/2002 drought had a severe impact. In 2002, growth production and mean population biomass reached similar values to those in 1993, but in the heat wave of 2003 and the drought associated with a 

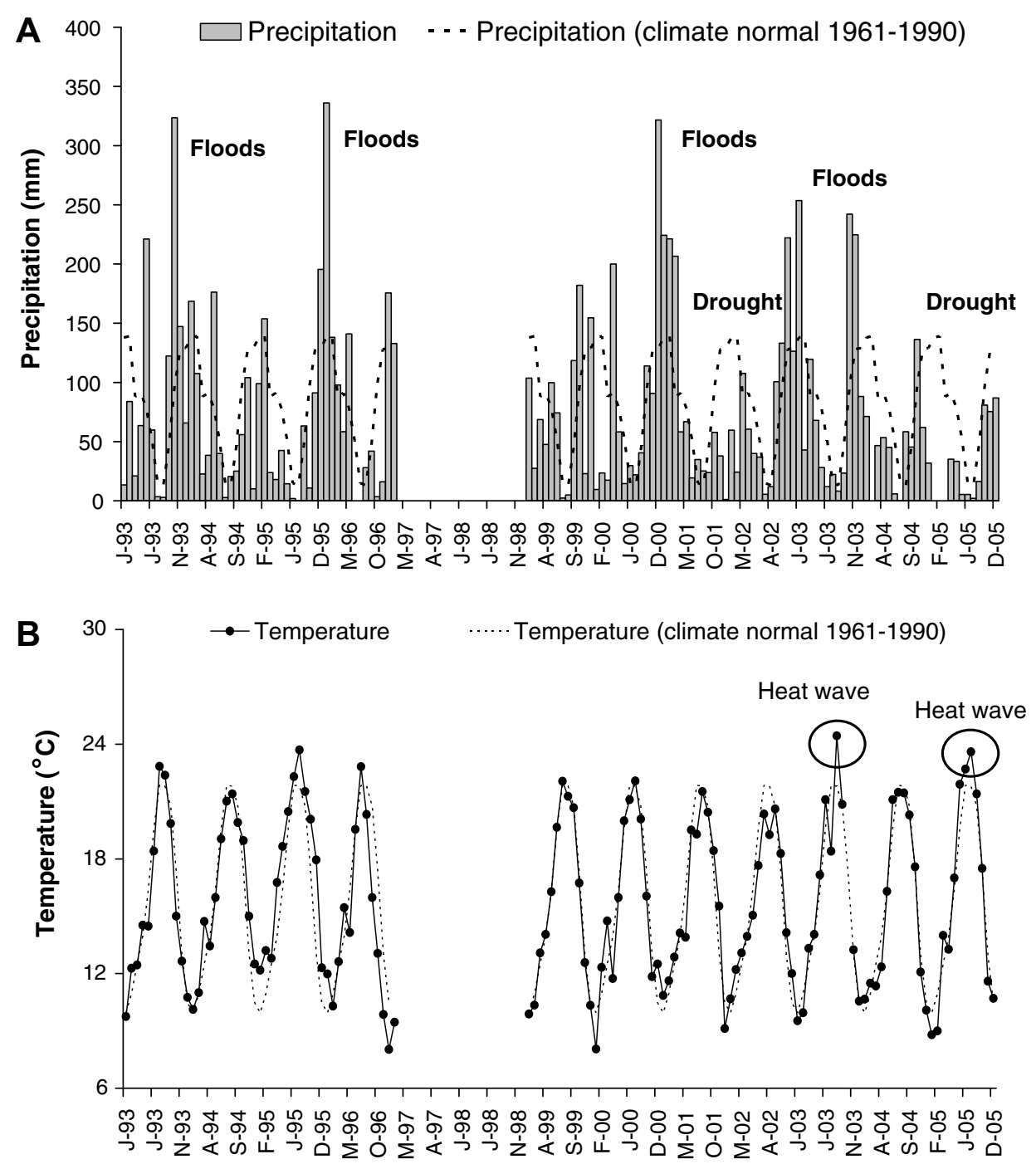

Fig. 4. Long-term variation in precipitation (A) and temperature (B) compared to the normal climate (normal climate of a climatic element is the mean value correspondent to a sufficient number of years to admit that it represents the predominant value of that element in a certain place. The World Meteorological Organization fixed that number in 30 years, starting in the first year of each decade (e.g. 1961-1990). The climate normal of 1961-1990 is considered a reference (IM - Portuguese Weather Institute, http://web.meteo.pt).

heat wave in 2005 seem to have reduced the resilience of this population.

In the eutrophic area, the pattern of change is very similar to that of the seagrass bed, but in 2004 and 2005 there was a substantial recovery of growth production and mean population biomass.

\section{Discussion}

Coastal ecosystems are subjected to multiple anthropogenic stressors, which 'usually do not operate independently, but often interact to produce combined impacts on biodiversity and ecosystem function (Vinebrooke et al., 2004; Dolbeth et al., 2007), as clearly seen for the Mondego. Over the last two decades, two distinct patterns can be seen in the Mondego estuary, the first corresponding to the eutrophication period (1993-1998) and the second related to the recovery phase, post-management (1999-
2005). In addition to the organic loading impact, the Mondego estuary has been subjected to consecutive extreme weather events (floods, droughts and heat waves), which had a strong negative impact on the two key components of the estuarine system. The available climate data reveal an increase both in the frequency of heavy precipitation events and in the frequency of severe and extreme droughts, as well as heat waves, especially over the last 10 years.

For H. ulvae, there were clear differences in population structure before and after the implementation of the management plan. In the seagrass bed during the eutrophication period, density and biomass declined abruptly concomitant with the seagrass decline. Through the postmanagement period, $H$. ulvae seemed to be recovering gradually until the winter of 2000/2001 when an intense flood removed much of the population out of the estuary. In the following winter of 2001/2002, an intense drought 

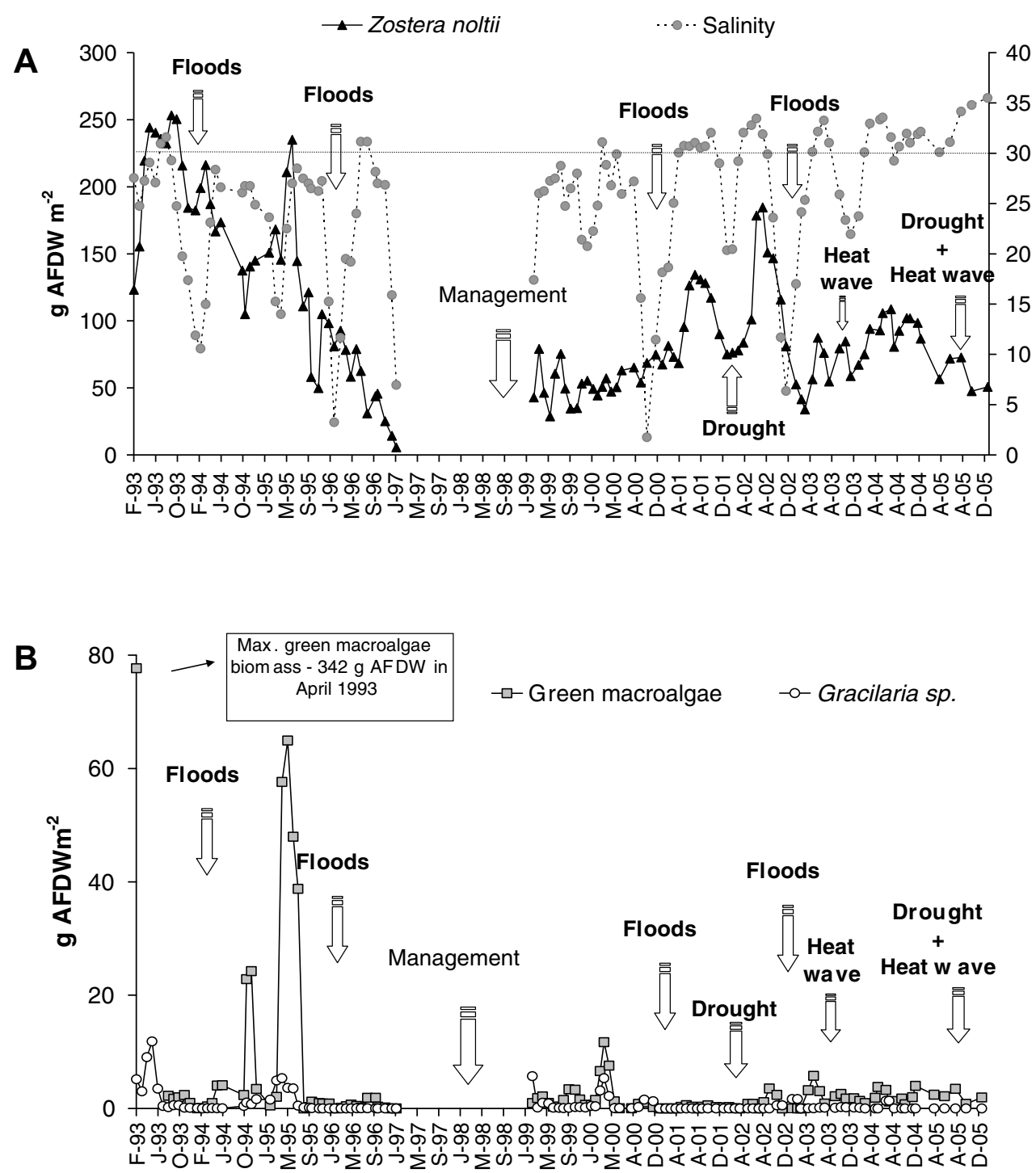

Fig. 5. Long-term variation of plant biomass. (A) Seagrass in the Z. noltii bed and (B) macroalgae in the Eutrophic area.

also negatively impacted this species, through the decline of its habitat Z. noltii. In 2002, the population recovered, reaching similar values to those in 1993, but in the following years consecutive extreme weather events led to a further decline in population density and biomass, preventing recovery.

This pattern is quite similar to that of the seagrass $Z$. noltii. This species showed signs of recovery after the implementation of management measures until the winter of 2001/2002, when an intense drought and consequently high salinity values $(>30)$ were associated with a decline. In 2002 , there was a slight recovery, but this was cut short in the following years due to a heat wave (2003) and again in 2005 by a further drought episode followed by a heat wave.

The upper limit of salinity tolerance of $Z$. noltii is relatively high. In southern locations, the plant occurs regularly above 29-35 (Perez-Llorens and Niell, 1993) and in Mauritania even above 35 (Wolff et al., 1993; Vermaat et al., 2000). Nevertheless, freshwater is beneficial for $Z$. noltii, as shown by Vermaat et al. (2000) with Dutch plants: survival was much lower at 35 in comparison to 15 . In SW Netherlands, the decline of $Z$. noltii beds coincided with salinities in excess of 30 (de Jong et al., 2004), consistent with our observations from the Mondego. During much of the recovery phase, salinity in the Mondego estuary ranged from 30 to 35 , perhaps explaining the weak recovery of the plant after the introduction of the management plan.

Extreme events seem to affect different components of the estuarine ecosystem differently. Whilst the floods directly impacted on $H$. ulvae, they did not directly affect the biomass of $Z$. noltii. In contrast, drought events, through their effects on salinity, directly affected the biomass of $Z$. noltii, which had knock-on effects on the dynamics of $H$. ulvae (Cardoso et al., 2005). Interestingly, whilst drought events negatively affected seagrass biomass, the areal extent of the beds was not reduced, in fact it increased, from 1.6 ha in 2002 to 4.0 ha in 2004. It is possible that the higher hydrodynamic regime now seen in 


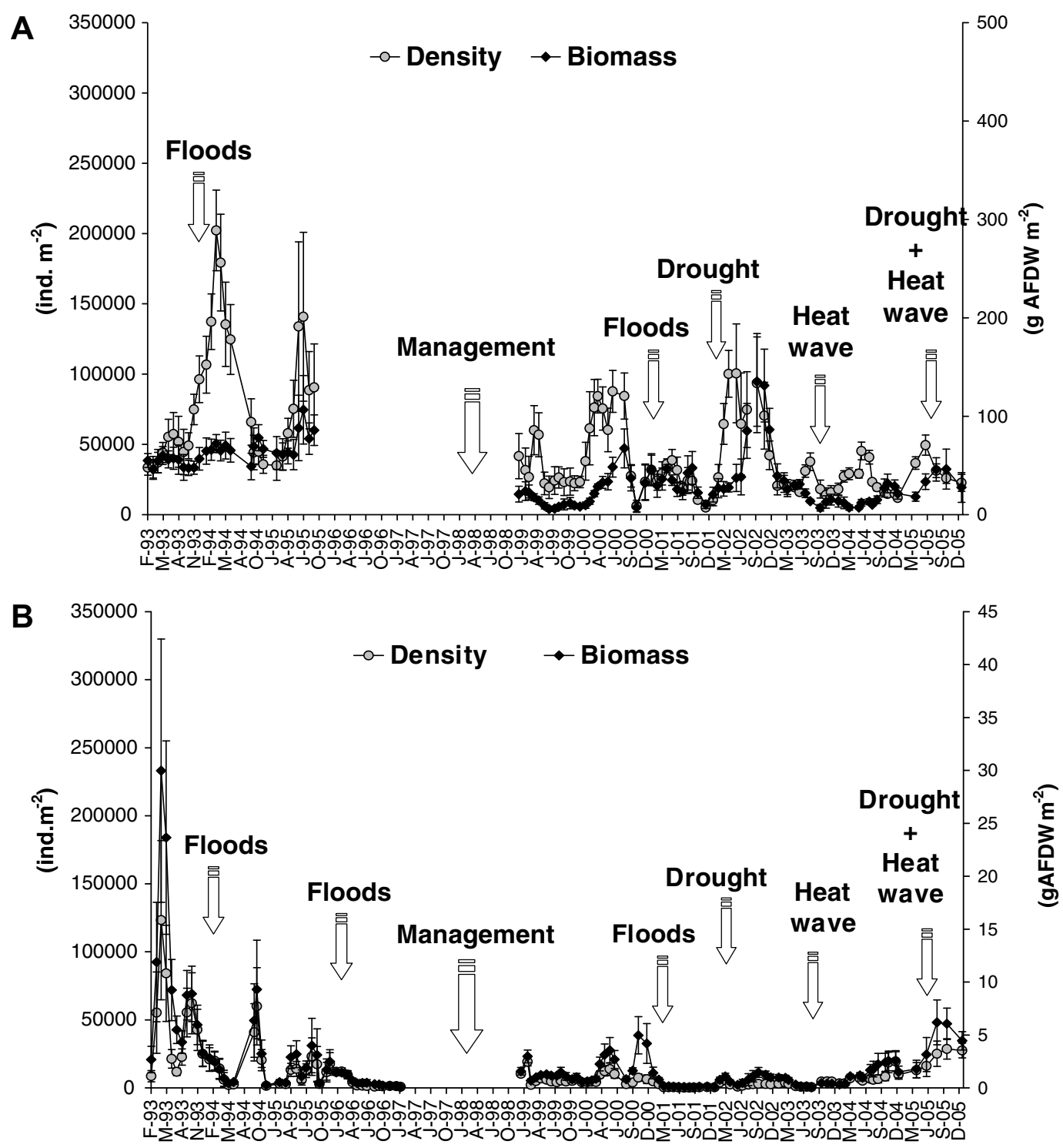

Fig. 6. Variation of H. ulvae density and biomass at the two study areas: (A) Z. noltii bed and (B) eutrophic area.

Table 1

Growth production estimations of $H$. ulvae for the seagrass bed and eutrophic area with connection to natural and anthropogenic events

\begin{tabular}{|c|c|c|c|c|c|c|c|c|}
\hline & \multicolumn{3}{|l|}{ Z. noltii bed } & \multicolumn{3}{|l|}{ Eutrophic area } & \multirow[t]{2}{*}{ Events } & \\
\hline & $P\left(\mathrm{~g} \mathrm{AFDW} \mathrm{m}^{-2} \mathrm{y}^{-1}\right)$ & $\bar{B}\left(\mathrm{~g} \mathrm{AFDW} \mathrm{m}^{-2}\right)$ & $P / \bar{B}$ & $\mathrm{P}\left(\mathrm{g} \mathrm{AFDW} \mathrm{m}^{-2} \mathrm{y}^{-1}\right)$ & $\bar{B}\left(\mathrm{~g} \mathrm{AFDW} \mathrm{m}^{-2}\right)$ & $P / \bar{B}$ & & \\
\hline 1993 & 125.08 & 59.24 & 2.11 & 45.73 & 9.37 & 4.87 & Eutrophication & Macroalgal bloom \\
\hline 1995 & - & - & - & 8.88 & 3.30 & 2.68 & & Some algae \\
\hline 1999 & 26.77 & 11.11 & 2.40 & 3.21 & 1.09 & 2.94 & Recovery & Management \\
\hline 2000 & 95.40 & 29.33 & 3.25 & 8.19 & 2.50 & 3.27 & & Intense floods \\
\hline 2003 & 29.71 & 21.84 & 1.36 & 1.43 & 0.44 & 3.26 & & Heat wave \\
\hline 2004 & 36.13 & 17.06 & 2.12 & 6.12 & 1.54 & 3.97 & & \\
\hline 2005 & 44.27 & 27.32 & 1.62 & 8.45 & 3.49 & 2.42 & & Drought + heat wave \\
\hline
\end{tabular}

- , no data available.

the south arm following management is contributing positively to the expansion of the seagrass, providing greater freshwater input.
In the eutrophic area, the density and biomass of $H$. ulvae declined throughout the study period, except in 2004 and 2005, when it showed some signs of recovery, 
probably due to the occurrence of higher green macroalgal biomass, in response to the drought conditions.

During the last decade, the literature on climate change impacts on marine systems has grown rapidly, providing strong evidence of distributional shifts (biogeographical and zonation patterns), changes in species composition, diversity and community structure and also changes in primary and secondary production (Scavia et al., 2002; Hays et al., 2005; Harley et al., 2006 and references therein). Floods are especially significant but their specific effects are difficult to predict: different communities and habitats may respond differently to flooding events, depending on the ecology and feeding habits of the species. Some benthic communities may experience negative impacts due to the anoxic conditions created by catastrophic terrigenous clay deposition (Norkko et al., 2002), whilst other communities dominated by opportunistic species may thrive under flood conditions (Salen-Picard and Arlhac, 2002; Salen-Picard et al., 2003). Also, floods can affect different components of food webs differentially, as pulses of organic matter lead to an increase of surface- and subsurface-deposit feeding assemblages.

We conclude that during the eutrophication period of the Mondego, extreme weather events contributed to the overall degradation of the estuary, while during the recovery phase those extreme weather episodes delayed the recovery process significantly. These observations add weight to general concerns that multiple stressors (in the present case, eutrophication + floods + heat waves + droughts) operating concurrently or consecutively can act synergistically to lower overall system stability. The loss of biodiversity following one stressor can lead to a decline of the resilience of that system to additional impacts, slowing the system's return to its previous state, highlighting the importance of ecological history in predicting responses to environmental change (Scheffer et al., 2001; Vinebrooke et al., 2004). Given that global climate change will occur over the next few years, global biodiversity loss will likely accelerate in the future, with potentially more frequent ecological collapses and ecosystem shifts (Sala and Knowlton, 2006).

\section{Acknowledgements}

This work was supported by FCT (Fundação para a Ciência e Tecnologia) through a Post-Doctoral grant to P.G. Cardoso (SFRH/BPD/22176/2005). The authors are indebted to all the colleagues that assisted in the field and lab work. A special thanks to Marieke Van Katwijk, University of Nijmegen, for sharing her experience and knowledge.

\section{References}

Adams, S.M., 2005. Assessing cause and effect of multiple stressors on marine systems. Marine Pollution Bulletin 51, 649-657.
Cardoso, P.G., Lillebø, A.I., Pardal, M.A., Ferreira, S.M., Marques, J.C., 2002. The effect of different primary producers on Hydrobia ulvae population dynamics: a case study in a temperate intertidal estuary. Journal Experimental Marine Biology and Ecology 277, 173-195.

Cardoso, P.G., Pardal, M.A., Lillebø, A.I., Ferreira, S.M., Marques, J.C., Raffaelli, D., 2004. Dynamic changes of seagrass assemblages under eutrophication and implications for recovery. Journal Experimental Marine Biology and Ecology 302, 233-248.

Cardoso, P.G., Brandão, A., Pardal, M.A., Raffaelli, D., Marques, J.C., 2005. The resilience of Hydrobia ulvae populations to anthropogenic and natural disturbances. Marine Ecology Progress Series 289, 191199.

Cardoso, P.G., Bankovic, M., Raffaelli, D., Pardal, M.A., 2007. Polychaete assemblages as indicators of habitat recovery in a temperate estuary under eutrophication. Estuarine Coastal and Shelf Science 71, 301-308.

Dauvin, J.C., 1986. Dynamique de la population d'Abra prismatica (Mollusque, Bivalve) de la baie de Morlaix (Manche Occidentale). Annales de l'Institute Océanographique 62, 1-12.

de Jong, D.J., van Katwijk, M.M., Jager, Z., 2004. Zeegras in Nederland. De Levende Natuur 105, 209-211.

Dolbeth, M., Cardoso, P.G., Ferreira, S.M., Verdelhos, T., Raffaelli, D., Pardal, M.A., 2007. Anthropogenic and natural disturbance effects on a macrobenthic estuarine community over a 10 -year period. Marine Pollution Bulletin 54, 576-585.

Ferreira, S.M., Pardal, M.A., Lillebø, A.I., Cardoso, P.G., Marques, J.C., 2004. Population dynamics of Cyathura carinata (Isopoda) in a eutrophic temperate estuary. Estuarine Coastal and Shelf Science 61, 669-677.

Harley, C.D.G. et al., 2006. The impacts of climate change in costal marine systems. Ecology Letters 9, 228-241.

Hays, G.C., Richardson, A.J., Robinson, C., 2005. Climate change and marine plankton. Trends in Ecology and Evolution 20, 337-344.

Lillebø, A.I., Neto, J.M., Martins, I., Verdelhos, T., Leston, S., Cardoso, P.G., Ferreira, S.M., Marques, J.C., Pardal, M.A., 2005. Management of a shallow temperate estuary to control eutrophication: the effect of hydrodynamics on the system's nutrient loading. Estuarine Coastal and Shelf Science 65, 697-707.

Martins, I., Pardal, M.A., Lillebø, A.I., Flindt, M.R., Marques, J.C., 2001. Hydrodynamics as a major factor controlling the occurrence of green macroalgal blooms in a eutrophic estuary: a case study on the influence of precipitation and river management. Estuarine Coastal and Shelf Science 52, 165-177.

Norkko, A. et al., 2002. Smothering of estuarine sandflats by terrigenous clay: the role of wind-wave disturbance and bioturbation in sitedependent macrofaunal recovery. Marine Ecology Progress Series 234, 23-41.

Pardal, M.A., Cardoso, P.G., Sousa, J.P., Marques, J.C., Raffaelli, D., 2004. Assessing environmental quality: a novel approach. Marine Ecology Progress Series 267, 1-8.

Perez-Llorens, J.L., Niell, F.X., 1993. Seasonal dynamics of biomass and nutrient content in the intertidal seagrass Zostera noltii Hornem. from Palmones River Estuary, Spain. Aquatic Botany 46, 49-66.

Sala, E., Knowlton, N., 2006. Global Marine Biodiversity Trends. Annual Review Environmental Resources 31, 93-122.

Salen-Picard, C., Arlhac, D., 2002. Long-term changes in a Mediterranean benthic community relationships between the polychaete assemblages and hydrological variations of the Rhône River. Estuaries 25, 11211130.

Salen-Picard, C., Arlhac, D., Alliot, E., 2003. Responses of a Mediterranean soft bottom community to short-term (1993-1996) hydrological changes in the Rhone river. Marine Environmental Research 55, 409427.

Santos, F.D., Forbes, K., Moita, R., 2002. Climate Change in Portugal. In: Scenarios, Impacts and Adaptation Measures - SIAM Project. Gradiva Publishers, Lisbon, Portugal, p. 456.

Scavia, D. et al., 2002. Climate change impacts on US coastal and marine ecosystems. Estuaries 25, 149-164. 
Scheffer, M., Carpenter, S., Foley, J.A., et al., 2001. Catastrophic shifts in ecosystems. Nature 413, 591-596.

Struyf, E., Van Damme, S., Meire, P., 2004. Possible effects of climate change on estuarine nutrient fluxes: a case study in the highly nutrified Schelde estuary (Belgium, The Netherlands). Estuarine Coastal and Shelf Science 60, 649-661.

Verdelhos, T., Neto, J.M., Marques, J.C., Pardal, M.A., 2005. The effect of eutrophication abatement on the bivalve Scrobicularia plana. Estuarine Coastal and Shelf Science 63, 261-268.

Vermaat, J.E., Verhagen, F.C.A., Lindenburg, D., 2000. Contrasting responses in two populations of Zostera noltii Hornem. to experimen- tal photoperiod manipulation at two salinities. Aquatic Botany 67, 179-189.

Vinebrooke, R.D., Cottingham, K.L., Norberg, J., Scheffer, M., Dodson, S.I., Maberly, S.C., Sommer, U., 2004. Impacts of multiple stressors on biodiversity and ecosystem functioning: the role of species cotolerance. Oikos 104, 451-457.

Wolff, W.J., Duiven, A.G., Duiven, N.P., Esselink, P., Gueye, A., Meijboom, A., Moerland, G., Zegers, J., 1993. Biomass of macrobenthic tidal flat fauna of the Banc D'Arguin, Mauritania. Hydrobiologia 258, 151-163. 